\title{
STUDY ON TOXICITY EFFECT OF BISPYRIBAC-SODIUM HERBICIDE ON EARTHWORMS BY FILTER PAPER AND SOIL MIXING METHOD
}

\author{
Mohamed Riad Fouad \\ Department of Pesticide Chemistry and Technology, Faculty of Agriculture, \\ Alexandria University, Alexandria, Egypt \\ DOI: https://doi.org/10.51193/IJAER.2021.7410
}

\begin{abstract}
Two techniques were used to assess the toxicity of the herbicide bispyribac-sodium on earthworms (Aporrectodea caliginosa) by filter paper contact test at 24, 48 and $72 \mathrm{~h}$ and soil mixing test at 5 and 10 day. The results obtained in filter paper contact test showed that the concentrations of $\leq 1 \mu \mathrm{g}$ a.i $\mathrm{mL}^{-1}$ for herbicide caused $0 \%$ mortality at $24 \mathrm{~h}$ and $0.01 \mu \mathrm{g}$ a.i $\mathrm{mL}^{-1}$ caused $0 \%$ mortality at $48 \mathrm{~h}$. BS showed the highest intrinsic toxicity to the worms with an $\mathrm{LC}_{50}$ value of $0.062 \mu \mathrm{g}$ a.i $\mathrm{mL}^{-1}$ at 72 -h compared to $\mathrm{LC}_{50}$ at $48 \mathrm{~h}$ was $38.9 \mu \mathrm{g}$ a.i $\mathrm{mL}^{-1}$ and $\mathrm{LC}_{50}$ at 24 $\mathrm{h}$ were $518.32 \mu \mathrm{g}$ a.i $\mathrm{mL}^{-1}$. The toxicity of BS on earthworms by soil mixing technique expressed as $\mathrm{LC}_{50}$ was increased when the exposure time was increased. The $\mathrm{LC}_{50}$ was reduced from 152.92 to 18.59 in clay soil, from 311.60 to 29.63 in clay soil: sandy clay loam soil (1:1) and from 448.23 to 33.67 in sandy soil at 5 and 10 days after treatment, respectively. The toxicity of tested pesticide was greater in clay soil at both time intervals than clay soil: sandy clay loam soil $(1: 1)$ and sandy clay loam soil.
\end{abstract}

Keywords: Toxicity; Bispyribac-sodium; Soil; Earthworms; Aporrectodea caliginosa

\section{INTRODUCTION}

Bispyribac-sodium (CAS No. 125401-75-4), sodium 2,6-bis [(4,6-dimethoxy-2-pyrimidinyl)oxy] benzoate, is a common systematic post-emergence herbicide used for the effective control of annual and perennial grasses, sedges and broad leaf weeds, such as Echinochloa species, in rice fields. Advantageous and unavoidable uses, herbicides often contaminate the water, soil and agricultural products causing public health hazards due to their high toxicity and long persistence (Qamruzzaman and Nasar, 2019). This gives rise to increasing interest in analyzing and monitoring the BS residue in rice and environments, i.e. soil, water and side effects on non-target organisms (Pareja et al., 2012). Reduction in the height of rice plants due to application of BS 
International Journal of Agriculture and Environmental Research

ISSN: 2455-6939

Volume: 07, Issue: 04 "July-August 2021"

has been observed. Hence, the agricultural application of BS is associated with a significant risk to the soil, aquatic system and water resources. Thus, the treatment of BS, after the fulfillment of its herbicidal applications, is essential to eliminate or at least minimize its negative impact especially on water resources and earthworms in soil (Qamruzzaman and Nasar, 2019). Earthworms are the most important soil invertebrates, accounting for $60-80 \%$ of the total soil biomass, and widely distributed in different soils of the world (Benckiser, 1997; Sun et al., 2019). Due to their digging, digesting and excreting activities, earthworms have strong abilities to transform soil structure, improve soil physio-chemical characters, microbial remove the activities and promote reactions, thereby directly and indirectly promote biodegradation of organic contaminants. Earthworms could also retard the binding of organic contaminants to soils, release previously soil-bound contaminants for subsequent degradation, and enhance the bioavailability of organic pollutants (Zhao et al., 2016). Previous researches have suggested that earthworms could assist the microbial degradations of many pesticides in soil, e.g., 2-Methyl-4chlorophenoxyacetic acid (Liu et al., 2011), pentachlorophenol (Li et al., 2015) and atrazine (Lin et al., 2018). Thus, it is supposed that addition of earthworms will possibly strengthen the microbial degradation of BS in soil. The characterization of contaminated sites and evaluation of remediation techniques usually involves the determination of contaminant concentration in the soil or other contaminated media (sediment, semisolid waste, etc.). However, for several decades it has become desirable, and in some cases truly necessary, to include bioassays for such characterization also. This is due to two factors. First, in the biodegradation or chemical transformation of soil contaminants, the contaminating compounds often are not mineralized completely, but other intermediates are produced. Usually, not all of the metabolites are known, and their toxicity is unknown. Second, many weathering processes, as well as bioremediation/chemical treatments, may not greatly reduce the concentration of the parent compound, but may reduce the bioavailability to sufficiently low levels to be only of minimal risk to public health and the environment. Thus, to characterize a site or treated material adequately, bioassays are needed in addition to chemical determinations (Domínguez-Rodríguez et al., 2020). The objectives of this study were to: (1) comparison of the toxicity of BS on earthworms (Aporrectodea caliginosa) by different techniques by filter paper contact test and soil mixing technique; and (2) effect of soil type on the toxicity of BS for Aporrectodea caliginosa.

\section{MATERIALS AND METHODS}

\subsection{Bispyribac-sodium}

IUPAC name: Sodium 2,6-bis[(4,6-dimethoxypyrimidin-2-yl)oxy] benzoate. The chemical class: Pyrimidinyl oxy benzoic acid. Product: Technical $98 \%$ a.i. Solubility $\left(20^{\circ} \mathrm{C}\right)$ : Water $7330 \mathrm{mg} / \mathrm{L}$. Pesticide type: Herbicide. Production Company: Sundat, AGROCHEM. Formulations: 
Bispyribac-sodium 1\% SC. Uses: Control of grasses, sedges and broad-leaved weeds, especially Echinochloa spp., in direct-seeded rice and weeds in non-crop situations.

\subsection{Tested soils}

There are two common types of the Egyptian soil, alluvial and calcareous. The soil samples were collected from the surface layer $(0-20 \mathrm{~cm})$ from different locations that had no history with the pesticides. The alluvial soil (clay soil) was collected from the Agricultural Research Station, Abis farm of the Faculty of Agriculture, University of Alexandria and the calcareous soil (sandy clay loam soil) collected from the Elnahda region, Elamria, Alexandria Governorate. The physical and chemical properties were determined at the Department of Soil and Water Sciences, Faculty of Agriculture, University of Alexandria and the data are presented in Tables (1 and 2). Soil samples were air-dried, ground and passed through a 2-mm sieve use. The soil texture was determined by the hydrometer method (Gee et al., 1986). Soil pH was measured using $0.01 \mathrm{M}$ calcium chloride $\left(\mathrm{CaCl}_{2}\right)$ in a 1:2 w/w soil: solution slurry. The OM content was determined by dichromate oxidation according to the Walkley-Black method (Nelson et al., 1996).

Table 1: Physical properties of the tested soils

\begin{tabular}{|c|c|c|c|c|c|c|}
\hline \multirow{2}{*}{$\begin{array}{l}\text { Soil } \\
\text { code }\end{array}$} & \multirow{2}{*}{ Soil type } & \multicolumn{3}{|c|}{ Particle size distribution (\%) } & \multirow{2}{*}{ Texture class } & \multirow{2}{*}{$\begin{array}{c}\text { Water holding } \\
\text { capacity }(\mathrm{mL} / \mathbf{1 0 0 g})\end{array}$} \\
\hline & & Clay & Silt & Sand & & \\
\hline 1 & Alluvial & 42 & 18 & 40 & Clay & 46 \\
\hline 2 & Calcareous & 20 & 13 & 67 & Sandy clay loam & 38 \\
\hline
\end{tabular}

Table 2: Chemical properties of the tested soils

\begin{tabular}{|c|c|c|}
\hline Chemical properties & Claysoil & Sandy clay loamsoil \\
\hline $\mathrm{EC}(\mathrm{m} \mathrm{mohs} / \mathrm{cm})$ at $25^{\circ} \mathrm{C}$ & 1.32 & 5.03 \\
\hline Soil pH & 8.25 & 8.15 \\
\hline Organic matter content $(\%)$ & 3.31 & 1.54 \\
\hline Total carbonate $(\%)$ & 7.87 & 44.64 \\
\hline \multicolumn{3}{|l|}{ Soluble cations conc. $(\mathrm{meq} / \mathrm{L})$ : } \\
\hline $\mathrm{Ca}^{++}$ & 3.8 & 18.7 \\
\hline
\end{tabular}


International Journal of Agriculture and Environmental Research

ISSN: 2455-6939

Volume: 07, Issue: 04 "July-August 2021"

\begin{tabular}{|c|c|c|}
\hline $\mathrm{Mg}^{++}$ & 5.0 & 8.8 \\
$\mathrm{Na}^{+}$ & 9.4 & 22.5 \\
$\mathrm{~K}^{+}$ & 0.5 & 0.3 \\
\hline Soluble anions conc. (meq/L): & \multicolumn{2}{|c|}{0.8} \\
\hline $\mathrm{CO}_{3}^{--}$ & 1.6 & 4.6 \\
$\mathrm{HCO}^{-}$ & 2.6 & 21.0 \\
$\mathrm{Cl}^{-}$ & 8.5 & 23.9 \\
$\mathrm{SO}_{4}^{-{ }^{-}}$ & 0.6 & 2.6 \\
\hline
\end{tabular}

\subsection{Earthworm}

Earthworms was used in this study belonged to species commonly found in Egypt (Aporrectodea caliginosa). Individual worms were collected from fields around Alexandria Governorate and reared in artificial soil in large plastic containers $(38 \times 60 \times 10 \mathrm{~cm})$ covered with muslin cloth to reduce water evaporation, as described by Heimbach (1984). The worms were maintained in the artificial soil at $23 \pm 2{ }^{\circ} \mathrm{C}$ for one month before the experiments. Earthworms used in this study were adults. As earthworms are hermaphrodite, no sexual differences are taken into account. The adults were removed from the artificial soil $24 \mathrm{~h}$ before use and stored in Petri dishes on damp filter paper (in the dark at $23 \pm 2^{\circ} \mathrm{C}$ ) to void gut contents (Li et al., 2020).

\subsection{Experiments}

\subsubsection{Contact toxicity of tested pesticide on earthworm by filter paper contact test}

The standard OECD Guidelines for contact toxicity protocol (OECD, 1984) was followed, glass Petri dishes and filter paper, $11.0 \mathrm{~cm}$ diameter were used (Addison and Holmes, 1995). The filter papers were treated with tested BS (Technical $98 \%$ ) solutions in acetone $(0.01,0.1,1,10,50$, $100,200,500,1000,2000$ and $4000 \mu \mathrm{g} / \mathrm{ml}$ ) to obtained final concentrations of BS in filter paper; $600,300,150,75,30,15,1.5,0.15,0.015$ and $0.0015 \mu \mathrm{g} / \mathrm{cm}^{2}$. After solvent evaporation, $1.5 \mathrm{~mL}$ water was added, and one earthworm (Aporrectodea caliginosa) was placed in each Petri dish to direct contact with pesticide, four earthworms were used as a replicate. With a plastic film to permit inner aeration, plates were covered and holed (Figure 1). Three replicates for each tested concentration as well as control were kept in a big box at the darkness to ambient temperature for 72 h. Every $24 \mathrm{~h}$, mortality and general aspect of all individuals was recorded and the $\mathrm{LC}_{50}$ values were calculated by LdP line software (Singh and Singh, 2015; Cheng et al., 2020). 
The earthworms was placed in glass Petri plates with a known diameter

(to know the exact quantity of pesticide $-\mu \mathrm{g} / \mathrm{cm}^{-2}$ )

The Petri dish was treated with tested BS solution $(0.01,0.1,1,10,50$, $100,200,500,1000,2000$ and $4000 \mu \mathrm{g} / \mathrm{ml})$

After solvent evaporation, $1.5 \mathrm{~mL}$ water was added and earthworms were placed (concentrations pesticide in Petri plates; 600, 300, 150, $75,30,15,1.5,0.15,0.015$ and $\left.0.0015 \mu \mathrm{g} / \mathrm{cm}^{2}\right)$

Three replicates for each concentration was kept at the darkness up to $72 \mathrm{~h}$

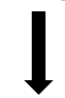

Every $24 \mathrm{~h}$, mortality and general aspect of all individuals was recorderd and the $\mathrm{LC}_{50}$ values was calculated

\section{Fig. 1: Schematic diagram of $\mathrm{LC}_{50}$ assessment of tested bispyribac-sodium on earthworm by residual film technique}

\subsubsection{Toxicity of tested BS on earthworm by soil mixing test}

In the soil mixing bioassay, the earthworms were adapted in the laboratory using artificial soil. The artificial soil was prepared using $70 \%$ sand, $20 \%$ kaolin clay, and $10 \%$ sphagnum peat moss, and the $\mathrm{pH}$ was adjusted to $6.0 \pm 0.5$ by the addition of $\mathrm{CaCO}_{3}$. Then, $200 \mathrm{~g}$ of artificial soil was placed in plastic boxes $(5 \times 10 \mathrm{~cm})$, the moisture content was adjusted to $35 \%$ of the final weight. In similar, using the tested claysoil, sandy clay loams soil and clay soil: sandy clay loams soil (1:1), the boxes were treated with aqueous solutions of herbicide BS formulations ( $1 \% \mathrm{SC})$ to obtain 1000, 500, 200, 100, 10 and $1 \mu \mathrm{g} / \mathrm{g}$ soil. Mature individuals weighting between 0.6 and $0.7 \mathrm{~g}$ were selected. Four prewashed and ventilated mature earthworms were then introduced into each box then (Three replicates for each concentration), covered with Parafilm and holed for aeration and placed in an incubation chamber at a temperature of $23 \pm 2^{\circ} \mathrm{C}$ with a $12: 12$ photoperiod. The control was prepared in a similar way except that only water was added to the soil. Lost moisture was replaced during assessment on a lost weight basis and the lost weight was replaced with distilled water (Figure 2). The percentage of mortality was monitored after 5 and 10 days. Earthworms were regarded as dead when they did not react to a mild mechanical stimulus. Also, the $\mathrm{LC}_{50}$ value of BS was calculated by LdP line software (Singh and Singh, 2015; Kavitha et al., 2020). 
$200 \mathrm{~g}$ of soil was placed in plastic boxes $(5 \mathrm{X} 10 \mathrm{~cm})$, moistened with distilled water $(40 \mathrm{~mL} /$ box $)$ and then treated with BS (1\% SC)

Four adults previously weighed was placed in each box, covered with Para film and holed for aeration

Three replicates (boxes) by concentration was used, and other for control

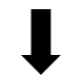

Other box was prepared to control humidity

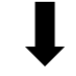

All boxes was kept into a large wooden box in the darkness to ambient temperature

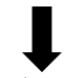

The percentage of mortality by each tested concentration was monitored and the $\mathrm{LC}_{50}$ values were calculated

\section{Fig. 2: Schematic diagram of $\mathrm{LC}_{50}$ assessment of tested bispyribac-sodium on earthworm by soil mixing technique}

\subsection{Statistical analysis}

Experimental data presented as $\mathrm{LC}_{50}$ statistical analysis was performed by the Ldp line software (Wang et al. 2012; Mohammed, 2020). A probit analysis developed by Chi (1997) was employed to assess the acute toxicity of BS to earthworm.

\section{RESULTS AND DISCUSSION}

\subsection{Toxicity of tested BS on earthworm by filter paper contact test}

Laboratory tests play an essential role in the risk assessment of chemicals such as pesticides toward earthworms and are considered valuable if they predict the impacts on earthworms under field conditions (Zhou et al., 2008). Among these, acute toxicity tests are considered the most relevant for laboratory testing, and earthworm mortality has been the main end point (Kandalkar and Naik, 2004). Although considering it to be of low ecological relevance, Heimbach (1992) found a reasonable correlation between the results of acute toxicity tests and the effects observed in the field. The results of acute toxicities of tested bispyribac-sodium by filter paper contact test demonstrated that widely varied in their contact toxicities to Aporrectodea caliginosa (Table 3 ). 
The results obtained showed that the concentrations of $\leq 0.15 \mu \mathrm{g} \mathrm{cm}^{-2}\left(1 \mu \mathrm{g}\right.$ a.i $\left.\mathrm{mL}^{-1}\right)$ for herbicide caused $0 \%$ mortality at $24 \mathrm{~h}$ and concentration of $0.0015 \mu \mathrm{g} \mathrm{cm}^{-2}\left(0.01 \mu \mathrm{g} \mathrm{a.i} \mathrm{mL} \mathrm{m}^{-1}\right)$ caused $0 \%$ mortality at $48 \mathrm{~h}$. The effect on earthworm death rate was negligible with lower mortality at $24 \mathrm{~h}$, indicating a very weak effect on earthworm compared to mortality at 48 and 72 h. In addition, the concentration of $500 \mu \mathrm{g}$ a.i $\mathrm{mL}^{-1}$ for the tested pesticide causes lower than $50 \%$ mortality at $24 \mathrm{~h}$. Shown $\mathrm{LC}_{5}, \mathrm{LC}_{50}, \mathrm{LC}_{95}$ and other parameters in Table 4 . BS showed the highest intrinsic toxicity to the worms with an $\mathrm{LC}_{50}$ value of $0.062(0.161-0.030) \mu \mathrm{g}$ a.i mL $\mathrm{m}^{-1}$ at 72-hcompared to $\mathrm{LC}_{50}$ at $48 \mathrm{~h}$ was $38.91(96.57-15.29) \mu \mathrm{g}$ a.i $\mathrm{mL}^{-1}$ and $\mathrm{LC}_{50}$ at $24 \mathrm{~h}$ was 518.32 (1046.64-258.67) $\mu \mathrm{g}$ a.i $\mathrm{mL}^{-1}$. The toxicity as mortality percentages were increased and $\mathrm{LC}_{50}$ value was reduced when the exposure time was increased for, indicating a positive correlation between the pesticide toxicity and exposure time (Tables 3 and 4).

Table 3: Toxicity of tested bispyribac-sodium (Mortality \% \pm SE) on earthworm by filter paper contact test

\begin{tabular}{|c|c|c|c|}
\hline Conc. $\left(\boldsymbol{\mu g} / \mathbf{c m}^{2}\right)$ & $\mathbf{2 4} \mathbf{~ h}$ & $\mathbf{4 8} \mathbf{~ h}$ & $\mathbf{7 2} \mathbf{~ h}$ \\
\hline $\mathbf{0 . 0 0 1 5}$ & $0.00 \pm 0.00$ & $0.00 \pm 0.00$ & $25.00 \pm 0.00$ \\
\hline $\mathbf{0 . 0 1 5}$ & $0.00 \pm 0.00$ & $8.33 \pm 0.33$ & $41.67 \pm 0.00$ \\
\hline $\mathbf{0 . 1 5}$ & $0.00 \pm 0.00$ & $16.67 \pm 0.33$ & $100.00 \pm 0.00$ \\
\hline $\mathbf{1 . 5}$ & $8.33 \pm 0.33$ & $25.00 \pm 0.58$ & $100.00 \pm 0.00$ \\
\hline $\mathbf{7 . 5}$ & $16.67 \pm 0.67$ & $33.33 \pm 0.33$ & $100.00 \pm 0.00$ \\
\hline $\mathbf{1 5}$ & $25.00 \pm 0.58$ & $50.00 \pm 1.15$ & $100.00 \pm 0.00$ \\
\hline $\mathbf{3 0}$ & $33.33 \pm 0.33$ & $75.00 \pm 0.00$ & $100.00 \pm 0.00$ \\
\hline $\mathbf{7 5}$ & $41.67 \pm 0.33$ & $83.33 \pm 0.67$ & $100.00 \pm 0.00$ \\
\hline $\mathbf{1 5 0}$ & $58.33 \pm 0.33$ & $100.00 \pm 0.00$ & $100.00 \pm 0.00$ \\
\hline $\mathbf{3 0 0}$ & $75.00 \pm 0.00$ & $100.00 \pm 0.00$ & $100.00 \pm 0.00$ \\
\hline $\mathbf{6 0 0}$ & $83.33 \pm 0.33$ & $100.00 \pm 0.00$ & $100.00 \pm 0.00$ \\
\hline
\end{tabular}

Table 4: Toxicity indeces and their parameters for herbicide bispyribac-sodium on earthworm by filter paper contact test

\begin{tabular}{|l|c|c|c|}
\hline Time $(\mathbf{h})$ & $\mathbf{2 4}$ & $\mathbf{4 8}$ & $\mathbf{7 2}$ \\
\hline $\mathbf{L C}_{\mathbf{5}} \mathbf{a}(\boldsymbol{\mu g} / \mathbf{m L})$ & 9.10 & 0.23 & 0.003 \\
\hline $\mathbf{C o n f e d e n c e ~ l i m i t s ~ a t ~ 9 5 \% ~}^{\mathbf{2}}$ & $48.41-1.56$ & $1.99-1.78$ & $0.0184-0.0003$ \\
\hline $\mathbf{L C}_{\mathbf{5 0}} \mathbf{b}(\boldsymbol{\mu g} / \mathbf{m L})$ & 518.32 & 38.91 & 0.062 \\
\hline $\mathbf{C o n f e d e n c e ~ l i m i t s ~ a t ~ 9 5 \% ~}^{\mathbf{9}}$ & $1046.64-258.67$ & $96.57-15.29$ & $0.161-0.030$ \\
\hline $\mathbf{L C}_{\mathbf{9 5}}(\boldsymbol{\mu} \mathbf{g} / \mathbf{m L})$ & 29495.26 & 6508.98 & 1.41 \\
\hline
\end{tabular}


International Journal of Agriculture and Environmental Research

ISSN: 2455-6939

Volume: 07, Issue: 04 "July-August 2021"

\begin{tabular}{|l|c|c|c|}
\hline Confedence limits at 95\% & $221156.10-4382.72$ & $65740.66-938.60$ & $14.36-0.25$ \\
\hline Slope $^{\mathbf{d}}$ & $0.937 \pm 0.0397$ & $0.740 \pm 0.021$ & $1.212 \pm 0.117$ \\
\hline$\chi^{\mathbf{2}}$ & 0.725 & 6.962 & 3.164 \\
\hline $\mathbf{P}$ & 0.994 & 0.324 & 0.419 \\
\hline
\end{tabular}

a: Concentration causing 5\% mortality. b: Concentration causing 50\% mortality. c: Concentration causing $95 \%$ mortality. Results ofLC $5, \mathrm{LC}_{50}$ and $\mathrm{LC}_{95}$ are expressed as mean of three replicates \pm standard error (SE). d: Slope of the concentration-mortality regression line. e: Chi square value.

\subsection{Toxicity of tested herbicide BS on earthworm by soil mixing test}

The soil mixing test was used to evaluate the toxicity of tested herbicide BS on earthworm, Aporrectodea caliginosa. The contact filter paper test is simpler, cheaper, and faster, and is designed in such a way that the earthworms are exposed to the toxicant both by contact and in the aquatic phase (Tripathi et al., 2010). This test is reported to be an excellent screening technique to assess relative toxicity (Grumiaux et al., 2010). In contrast, the soil mixing test is more representative of the natural earthworm environment, and the chemicals are absorbed mainly by the gut in this method (Udovic and Lestan, 2010). Thus, the soil mixing test is more practical when the pesticide toxicities to earthworms are assessed (Wang et al., 2012). Table (5) shows the mortality percentages of earthworms exposed to bispyribac-sodium (SC 1\%) at concentrations of $0,1,10,100,500$ and $1000 \mu \mathrm{g} / \mathrm{g}$ soil at time 5 and 10 days after treatment in clay, clay : sandy clay loam (1:1) and sandy clay loam soil. The highest mortality percentage for BS at $1000 \mu \mathrm{g} / \mathrm{g}$ soil, was $100 \%$ at 10 days in three soils while she was 91.67, 83.33 and 66.67 $\%$ at 5 days in clay, clay: sandy clay loam (1:1) and sandy clay loam soil, respectively. The lowest tested concentration of BS $(1 \mu \mathrm{g} / \mathrm{g}$ soil) caused 0.00 and $25.00 \%$ mortality in clay soil, 0.00 and $16.67 \%$ mortality in clay : sandy clay loam (1:1) and sandy soil at 5 and 10 days after treatment, respectively. Toxicity data of BS from the soil mixing test showed a clear concentration-dependent relationship, and the mortality of earthworms was increased when the exposure time was increased. BS herbicide has been exhibited different levels of toxicity to earthworms, this result is in agreement with those obtained by Cang et al. (2017). Also, Singh and Singh (2015), pointed out that the toxicity of 2,4-D on earthworm (Eutyphoeus waltoni) was both time and dose-dependent. The toxicity of BS on earthworm by soil mixing technique expressed as $\mathrm{LC}_{50}$ was increased when the exposure time was increased. The $\mathrm{LC}_{50}$ was reduced from 152.92 (479.5-48.37) to 18.59 (68.54-4.37) in clay soil, from 311.60 (977.11-102.64) to 29.63 (93.78-8.72) in clay soil: sandy clay loam soil (1:1) and from 448.23 (4431.55-56.99) to 33.67 (115.51-9.16) in sandy soil at 5 and 10 days after treatment, respectively. The lower the LC $_{50}$ value the more toxic the chemical (Karasu and Koksal, 2005). The toxicity of tested pesticide was greater (lower $\mathrm{LC}_{50}$ ) in clay soil at both time intervals than that in clay soil: sandy clay loam soil (1:1) and sandy clay loam soil (Table 6). 
International Journal of Agriculture and Environmental Research

ISSN: 2455-6939

Volume: 07, Issue: 04 "July-August 2021"

Table 5: Toxicity of bispyribac-sodiumon earthworm (Mortality $\% \pm \mathrm{SE}$ ) by soil mixing test

\begin{tabular}{|c|c|c|c|c|c|c|}
\hline Soil & $\begin{array}{c}\text { Conc. } \\
(\boldsymbol{\mu g} / \mathbf{g} \text { soil) }\end{array}$ & $\mathbf{1}$ & $\mathbf{1 0}$ & $\mathbf{1 0 0}$ & $\mathbf{5 0 0}$ & $\mathbf{1 0 0 0}$ \\
\hline & \multirow{2}{*}{$\mathbf{5}^{\text {th }}$ day } & 0.00 & 25.00 & 33.33 & 50.00 & 91.67 \\
& & \pm 0.00 & \pm 0.58 & \pm 0.88 & \pm 0.00 & \pm 0.33 \\
& \multirow{2}{*}{$\mathbf{1 0}^{\text {th }}$ day } & 25.00 & 41.67 & 58.33 & 75.00 & 100.00 \\
& \pm 0.00 & \pm 0.33 & \pm 0.33 & \pm 0.58 & \pm 0.00 \\
\hline \multirow{3}{*}{ Clay : Sandy } & \multirow{2}{*}{$\mathbf{5}^{\text {th }}$ day } & 0.00 & 16.67 & 25.00 & 41.67 & 83.33 \\
clay loam $(\mathbf{1 : 1 )}$ & \multirow{2}{*}{$\mathbf{1 0}^{\text {th }}$ day } & \pm 0.00 & \pm 0.33 & \pm 0.58 & \pm 1.20 & \pm 0.33 \\
& & \pm 0.33 & 33.33 & 66.67 & 66.67 & 100.00 \\
& \multirow{2}{*}{$5^{\text {th }}$ day } & 0.00 & 25.00 & 25.00 & 41.67 & 66.67 \\
Sandy clay & & \pm 0.00 & \pm 0.58 & \pm 0.58 & \pm 0.33 & \pm 0.33 \\
loam & \multirow{2}{*}{$\mathbf{1 0}^{\text {th }}$ day } & 16.67 & 41.67 & 50.00 & 66.67 & 100.00 \\
& & \pm 0.33 & \pm 0.33 & 0.58 & \pm 0.67 & \pm 0.00 \\
\hline
\end{tabular}

Table 6: Toxicity indeces and their parameters for herbicide bispyribac-sodium on earthworm by soil mixing test

\begin{tabular}{|l|c|c|c|}
\hline Soil Types & Clay Soil & $\begin{array}{c}\text { Clay soil : Sandy Clay } \\
\text { Loam Soil (1:1) }\end{array}$ & $\begin{array}{c}\text { Sandy Clay } \\
\text { Loam Soil }\end{array}$ \\
\hline Time (day) & \multicolumn{3}{|c|}{$\mathbf{5}^{\text {th }}$ day } \\
\hline LC5 & 1.16 & 3.17 & 0.16 \\
\hline Upper/Lpower & $35.70-0.03$ & $59.217-0.123$ & $288.84-0.00002$ \\
\hline LC50 & 152.92 & 311.60 & 448.23 \\
\hline Upper/Lpower & $479.5-48.37$ & $977.11-102.64$ & $4431.55-56.99$ \\
\hline LC95 & 20165.11 & 30667.8 & 1288728 \\
\hline Upper/Lpower & $854408-733$ & $1418364-973.998$ & $0.00-99.80$ \\
\hline Slope & $0.776 \pm 0.07$ & $0.825 \pm 0.079$ & $0.48 \pm 0.07$ \\
\hline Chi Square & 4.281 & 3.547 & 1.09 \\
\hline Probability (P) & 0.118 & 0.17 & 0.58 \\
\hline Time (day) & & $\mathbf{1 0}^{\text {th }}$ day \\
\hline LC5 & 0.06 & 0.18 & 0.13 \\
\hline Upper/Lpower & $1.599-0.0007$ & $2.625-0.006$ & $2.60-0.00$ \\
\hline LC50 & 18.59 & 29.63 & 33.67 \\
\hline Upper/Lpower & $68.54-4.37$ & $93.78-8.72$ & $115.51-9.16$ \\
\hline
\end{tabular}


International Journal of Agriculture and Environmental Research

ISSN: 2455-6939

Volume: 07, Issue: 04 "July-August 2021"

\begin{tabular}{|l|c|c|c|}
\hline LC95 & 5963.65 & 5012.7 & 9227.94 \\
\hline Upper/Lpower & $174740-453$ & $85539.48-519.75$ & $264815-660.33$ \\
\hline Slope & $0.654 \pm 0.029$ & $0.738 \pm 0.031$ & $0.675 \pm 0.03$ \\
\hline Chi Square & 2.986 & 3.756 & 4.278 \\
\hline Probability (P) & 0.687 & 0.562 & 0.585 \\
\hline
\end{tabular}

\section{REFERENCES}

[1] Addison J. A.; Holmes S. B. (1995). Comparison of forest soil microcosm and acute toxicity studies for determining effects of fenitrothion on earthworms. Ecotoxicology and Environmental Safety. 30(2): 127-133.

[2] Benckiser G. (Ed.). (1997). Fauna in soil ecosystems: recycling processes, nutrient fluxes, and agricultural production. CRC Press.

[3] Cang T.; Dai D.; Yang G.; Yu Y.; Lv L.; Cail L.; Wang Q.; Wang Y. (2017). Combined toxicity of imidacloprid and three insecticides to the earthworm, Eiseniafetida (Annelida, Oligochaeta). Environmental Science and Pollution Research. 24: 8722-8730.

[4] Cheng Y.; Zhu L.; Song W.; Jiang C.; Li B.; Du Z.; Zhang K. (2020). Combined effects of mulch film-derived microplastics and atrazine on oxidative stress and gene expression in earthworm (Eiseniafetida). Science of The Total Environmental. 746: 141280.

[5] Chi H. (1997). Computer program for the probit analysis. National Chung Hsing University, Taichung, Taiwan.

[6] Domínguez-Rodríguez V. I.; Adams R. H.; Sánchez-Madrigal F.; Pascual-Chablé J. D. L. S.; Gómez-Cruz R. (2020). Soil contact bioassay for rapid determination of acute toxicity with Eiseniafoetida. Heliyon.6(1), e03131.

[7] Gee G. W.; Bauder J. W.; Klute A. (1986). Particle-size analysis. Methods of soil analysis Part 1 Physical and Mineralogical Methods.383-411.

[8] Grumiaux F.; Demuynck S.; Schikorski D.; Lemière S.; Leprêtre A. (2010). Assessing the effects of FBC ash treatments of metal-contaminated soils using life history traits and metal bioaccumulation analysis of the earthworm Eiseniaandrei. Chemosphere. 79: 156161.

[9] Heimbach F. (1984). Correlation between three methods for determining the toxicity of chemicals to earthworms. Pesticide Science. 15(6): 605-611.

[10] Heimbach F. (1992). Effects of pesticides on earthworm populations: comparison of results from laboratory and field tests. In: Greig-Smith, P.W., Becker, H., Edwards, P.J., Heimbach, F. (Eds.), Ecotoxicology of Earthworms. Springer Verlag, Intersept, UK, pp. 100-106. 
International Journal of Agriculture and Environmental Research

ISSN: 2455-6939

Volume: 07, Issue: 04 "July-August 2021"

[11] Kandalkar R. K.; Naik R. L. (2004).Acute toxicity of certain conventional agro-pesticides on earthworm, a non-target organism. Journal for Nature Conservation. 16: 369-376.

[12] Karasu B. A.; Koksal G. K. (2005).The acute toxicity of ammonia on tilapia (Oreochromis leucostictus L.) larvae and fingerlings. Turkish Journal of Veterinary and Animal Sciences. 29(2): 339-344.

[13] Kavitha V.; Anandhan R.; Alharbi N. S.; Kadaikunnan S.; Khaled J. M.; Almanaa T. N.; Govindarajan M. (2020). Impact of pesticide monocrotophos on microbial populations and histology of intestine in the Indian earthworm Lampitomauritii (Kinberg). Microbial Pathogenesis. 139: 103893.

[14] Li R.; Meng Z.; Sun W.; Wu R.; Jia M.; Yan S.; Zhou Z. (2020). Bioaccumulation and toxic effects of penconazole in earthworms (Eiseniafetida) following soil exposure. Environmental Science and Pollution Research. 27(30): 38056-38063.

[15] Li X.; Lin Z.; Luo C.; Bai J.; Sun Y.; Li Y. (2015). Enhanced microbial degradation of pentachlorophenol from soil in the presence of earthworms: Evidence of functional bacteria using DNA-stable isotope probing. Soil Biology and Biochemistry.81: 168-177.

[16] Lin Z.; Zhen Z.; Ren L.; Yang J.; Luo C.; Zhong L.; Zhang D. (2018). Effects of two ecological earthworm species on atrazine degradation performance and bacterial community structure in red soil. Chemosphere.196: 467-475.

[17] Liu Y. J.; Zaprasis A.; Liu S. J.; Drake H. L.; Horn M. A. (2011). The earthworm Aporrectodea caliginosa stimulates abundance and activity of phenoxy alkanoic acid herbicide degraders. The ISME journal. 5(3): 473-485.

[18] Mohammed A. O. W. (2020). Evaluation of Fiprol, ImIdaprid and Dueracide Insecticides against Larval Stage of Red Palm Weevil Rhynchophorus Ferrugineus (Olivier) in Makkah Al-Mukarramah Region. Biosciences Biotechnology Research Asia.17(2): 319.

[19] Nelson D. W.; Sommers L. E.; Sparks D.; Page A.; Helmke P.; Loeppert R.; Soltanpour P.; Tabatabai M.; Johnston C.; Sumner M. (1996). Total carbon, organic carbon, and organic matter. Methods of soil analysis Part 3-chemical methods. 961-1010.

[20] OECD (1984) Guidelines for the testing of chemicals. No. 207 Earthworm acute toxicity tests, OECD, Paris, France.

[21] Pareja L.; Colazzo M.; Pérez-Parada A.; Besil N.; Heinzen H.; Böcking B.; FernándezAlba A. R. (2012). Occurrence and distribution study of residues from pesticides applied under controlled conditions in the field during rice processing. Journal of Agricultural and Food Chemistry. 60(18): 4440-4448.

[22] Qamruzzaman; Nasar A. (2019). Degradative treatment of bispyribac-sodium herbicide from synthetically contaminated water by colloidal $\mathrm{MnO}_{2}$ dioxide in the absence and presence of surfactants. Environmental Technology. 40(4): 451-457. 
[23] Singh V.; Singh K. (2015). Toxic Effect of Herbicide 2,4-D on the Earthworm Eutyphoeuswaltoni Michaelsen. Environmental Processes. 2: 251-260.

[24] Sun Y.; Zhao L.; Li X.; Hao Y.; Xu H.; Weng L.; Li Y. (2019). Stimulation of earthworms (Eiseniafetida) on soil microbial communities to promote metolachlor degradation. Environmental pollution. 248: 219-228.

[25] Tripathi G.; Kachhwaha N.; Dabi I. (2010). Comparative studies on carbofuran induced changes in some cytoplasmic and mitochondrial enzymes and proteins of epigeic, anecic and endogeic earthworms. Pesticide Biochemistry and Physiology. 96: 30-35.

[26] Udovic M.; Lestan D. (2010). Eiseniafetida avoidance behavior as a tool for assessing the efficiency of remediation of $\mathrm{Pb}, \mathrm{Zn}$ and $\mathrm{Cd}$ polluted soil. Environmental Pollution. 158: 2766-2772.

[27] Wang D.; Naito H.; Nakajima T. (2012).The toxicity of fenitrothion and permethrin. Insecticides-Pest Engineering. 85-98.

[28] Zhao L.; Zhu L.; Zhao S.; Ma X. (2016). Sequestration and bioavailability of perfluoroalkyl acids (PFAAs) in soils: Implications for their underestimated risk. Science of the Total Environment.572: 169-176.

[29] Zhou S. P.; Duan C. P.; Wang X. H.; Michelle W. H. G.; Yu Z. F.; Fu F. (2008). Assessing cypermethrin-contaminated soil with three different earthworm test methods. Journal Environmental Science. 20: 1381-1385. 